\title{
Performance Analysis of UMTS Cellular Network using Sectorization Based on Capacity and Coverage
}

\author{
A.K.M Fazlul Haque, Mir Mohammad Abu Kyum, \\ Md. Baitul Al Sadi, Mrinal Kar \\ Department of Electronics and Telecommunication \\ Engineering. \\ Daffodil International University
}

\author{
Md. Fokhray Hossain \\ Department of Computer Science and Engineering. \\ Daffodil International University
}

\begin{abstract}
Universal Mobile Telecommunications System (UMTS) is one of the standards in 3rd generation partnership project (3GPP). Different data rates are offered by UMTS for voice, video conference and other services. This paper presents the performance of UMTS cellular network using sectorization for capacity and coverage. The major contribution is to see the impact of sectorization on capacity and cell coverage in 3G UMTS cellular network. Coverage and capacity are vitally important issues in UMTS cellular Network. Capacity depends on different parameters such as sectorization, energy per bit noise spectral density ratio, voice activity, inter-cell interference and intra-cell interference, soft handoff gain factor, etc and coverage depends on frequency, chip rate, bit rate, mobile maximum power, MS Antenna Gain, EIRP, interference Margin, Noise figure etc. Different parameters that influence the capacity and coverage of UMTS cellular network are simulated using MATLAB 2009a. In this paper, the outputs of simulation for increasing amount of sectorization showed that the number of users gradually increased. The coverage area also gradually increased.
\end{abstract}

Keywords-UMTS; Capacit; Coverage and data rates; sectoring.

\section{INTRODUCTION}

A cellular cell can be divided into number of geographic areas, called sectors. It may be 3 sectors, 4 sectors, 6 sectors etc. When sectorization is done in a cell, interference is significantly reduced resulting in better performance for cellular network. Capacity in WCDMA standards of UMTS refers to maximum number of users per cell, where the area covered by RF signal from Node B or UE (User Equipment) is called coverage area of UMTS. Capacity and coverage are two dynamic phenomena in UMTS network. Parameters that define capacity and coverage of UMTS are dynamic in nature, where increasing or decreasing values of these parameters affects capacity and coverage of UMTS cellular network. One of the parameters is sectorization in UMTS. There are some works on sectorization scheme [1-4].

Bo Hagerman, Davide Imbeni and Jozsef Barta considered WCDMA 6-sector deployment case study of a real installed UMTS-FDD network [1]. Romeo Giuliano, Franco Mazzenga, Francesco Vatalaro described Adaptive Cell Sectorization for UMTS Third Generation CDMA Systems [2]. Achim Wacker, Jaana Laiho-Steffens, Kari Sipila, and Kari Heiska considered the impact of the base station sectorisation on WCDMA radio network performance [3]. S. Sharma, A.G. Spilling and A.R. Nix considered Adaptive Coverage for UMTS Macro cells based on Situation Awareness [4]. Most of the works analyzed the performance considering sectors with static parameters but it is needed to analyze the performance along with all dynamic parameters.

This paper optimizes the performance of both capacity and coverage of UMTS not only considering sectors but also with dynamic parameters as energy per bit noise spectral density ratio, voice activity, inter-cell interference, soft handoff factor, and data rates.

\section{BACKGROUND}

\section{A. Capacity in WCDMA for UMTS:}

As the downlink capacity of UMTS is related to transmit power of Node B and uplink capacity is related to numbers of users, uplink capacity is considered in this paper.

If the number of users is $\mathrm{N}_{\mathrm{s}}$ then for a single CDMA cell, the number of users will be [5],

$$
N_{s}=1+\left(\frac{W / R}{E_{b} / N_{o}}-\frac{\eta}{S}\right) \frac{1}{\alpha}
$$

Where, $\mathrm{N}_{\mathrm{s}=}$ total number of users, $\mathrm{W}=$ chip rate,

$\mathrm{R}=$ base band information bit rate, $\mathrm{E}_{\mathrm{b}} / \mathrm{N}_{\mathrm{o}}=$ Energy per bit to noise power spectral density ratio, $\eta=$ background thermal noise, $\mathrm{S}=$ signal power=S1-P (d)-shadow fading, S1=UE power, $\mathrm{P}(\mathrm{d})=$ Propagation loss.

For WCDMA, the chip rate is 3.84 Mcps [8], and the channel bandwidth is $5 \mathrm{MHz}$ [8]. It is also necessary to consider the affects of multiple cells or intra-cell interference $(\beta)[12]$, cell sectoring(D)[6], soft handover factor(H)[11], Array antenna gain $\left(\mathrm{A}_{\mathrm{g}}\right)[10]$.Thus the capacity for WCDMA in UMTS yields:

$$
N_{s}=1+\left(\frac{W / R}{E_{b} / N_{o}}-\frac{\eta}{S}\right) \frac{1}{(1+\beta) \alpha} \times D \times H \times A_{g}
$$

\section{B. Coverage and data rates in WCDMA for UMTS:}

UMTS offered different data rates for multi services. Table 1 shows different standard bit rates offered by UMTS. Higher class of service makes cell radius small resulting in small 
coverage area. If different class of services is classified in terms of coverage area, it will look like figure 1 .

TABLE 1: DIFFERENT CLASSES OF SERVICES

\begin{tabular}{|c|c|}
\hline Bit Rate(Kbps) & Class \\
\hline 12.2 & Class 5 \\
\hline 32 & Class 4 \\
\hline 64 & Class 3 \\
\hline 144 & Class 2 \\
\hline 384 & Class 1 \\
\hline
\end{tabular}

Figure 1 shows that for service class 1, maximum distance is observed by UE (User Equipment) from Node B. Similarly for service class 2 and service class 3, UEs maintain maximum distance from Node B. From this figure it is clear that different coverage areas are needed to maintain different data rates. So coverage area needs to increase for better class of services. This paper optimizes the coverage area for particular services with sectors.

Figure 2 shows a UMTS cell where Node B received power $\left(\mathrm{P}_{\mathrm{R}}\right)$ from User Equipment (UE). The Node B sensitivity is the power level for minimum signal necessary at the input of the Node $B$ receiver to meet requirements in terms of $E_{b} / N_{o}$, processing gain $\left(\mathrm{G}_{\mathrm{p}}\right)$ and Node $\mathrm{B}$ interference and noise power given as [8]

Node $B$ sensitivity $=E_{b} / N_{o}-G_{p}+N_{\text {Node } B \text { interference and noise power }}$ Where $\mathrm{G}_{\mathrm{p}}=$ Processing gain $=10 \log \left(\frac{\text { Chiprate }}{\text { Bitrate }}\right)=10 \log \left(\frac{3.84 M c p s}{R}\right)$

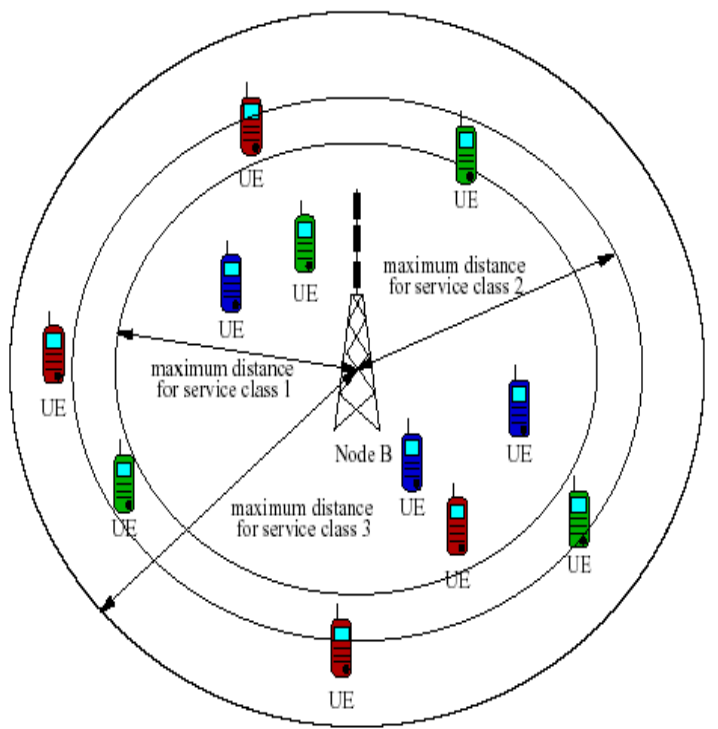

Figure 1: Different Classes of Services vs. Maximum Distance

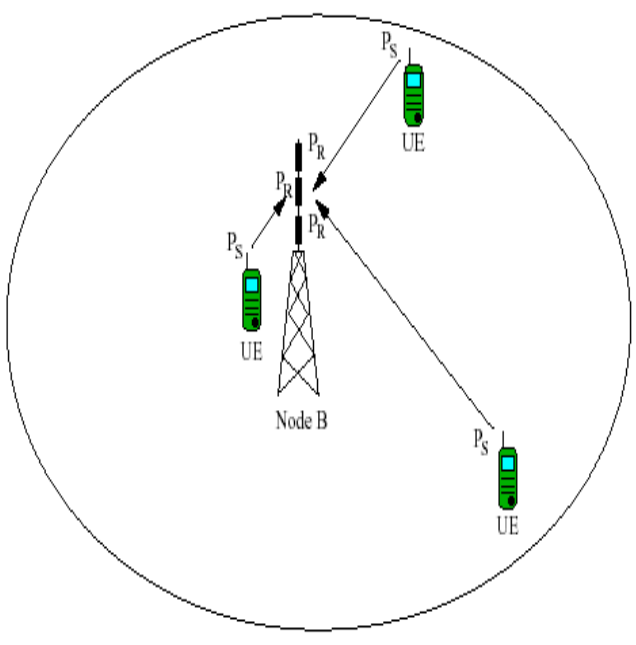

Figure 2: UMTS cell

Now the maximum allowable path loss for Node B, (iii)

$\mathrm{L}_{\mathrm{P}}=\mathrm{EIRP}-\mathrm{Node} \mathrm{b}$ sensitivity $+\mathrm{G}_{\mathrm{p}}$ - fast fading margin-----

from radio propagation model, Path loss for dense urban area [5],

$L=46.3+33.9 \log \left(f_{c}\right)-13.82 \log h_{b}-3.2$

$\left[\log \left(11.75 \mathrm{~h}_{\mathrm{UE}}\right)\right]^{2}+4.97+(44.9-6.55$

$\left.\log h_{\text {NodeB }}\right) \log d+3$

From equation (iii) and (iv) a relationship can be expressed for coverage and data rates in dense urban case,

$46.3+33.9 \log \left(f_{c}\right)-13.82 \log h_{b}-3.2$

$\left[\log \left(11.75 \mathrm{~h}_{\mathrm{UE}}\right)\right]^{2}+4.97+(44.9-6.55$

$\left.\log h_{\text {NodeB }}\right) \log d+3=$ EIRP - NodeB sensitivity

$+10 \log \left(\frac{\text { Chip rate }}{R}\right)$ - Fast fading Margin

where $\mathrm{d}$ is the coverage radius and $\mathrm{R}$ is the data rates.

After calculating the cell range d, the coverage area can be calculated. The coverage area for one cell in hexagonal configuration can be estimated with [9]

Coverage area, $\mathrm{S}=\mathrm{K} \cdot \mathrm{d}^{2}$

where $\mathrm{S}$ is the coverage area, $\mathrm{d}$ is the maximum cell range, and $\mathrm{K}$ is a constant. In Table 2, some of the $\mathrm{K}$ values are listed.

TABLE 2: K VALUES FOR THE SITE AREA CALCULATION [9]:

\begin{tabular}{|l|l|l|l|l|}
\hline $\begin{array}{l}\text { Site } \\
\text { configuration }\end{array}$ & $\begin{array}{l}\text { Omni } \\
\text { or no } \\
\text { sector }\end{array}$ & $\begin{array}{l}\text { Two } \\
\text { sectors }\end{array}$ & $\begin{array}{l}\text { Three } \\
\text { sectors }\end{array}$ & $\begin{array}{l}\text { Four } \\
\text { sectors }\end{array}$ \\
\hline Value of K & 2.6 & 1.3 & 1.95 & 2.6 \\
\hline
\end{tabular}




\section{SimULATIONS AND RESULTS}

The analysis has been done for capacity and coverage with sectoring cell for dense urban using MATLAB R2009a. The simulated values for sectorization are shown in Table 3 , Table 4, Table 5, Table 6 and Table 7. The performances are also described in Figure 3, Figure 4, Figure 5, Figure 6, and Figure 7. The algorithms of the evaluation process have also been introduced in appendix.

Figure 3 shows that Energy per bit to noise spectral density ratio $\left(\mathrm{E}_{\mathrm{b}} / \mathrm{N}_{\mathrm{o}}\right)$ needs to maintain small value for increasing number of simultaneous $384 \mathrm{Kbps}$ users. From this figure it is observed that for dynamic value of $\mathrm{E}_{\mathrm{b}} / \mathrm{N}_{\mathrm{o}}$ with changing the sectors, the number of simultaneous $384 \mathrm{Kbps}$ data users increased or decreased. For example, if $\mathrm{E}_{\mathrm{b}} / \mathrm{N}_{\mathrm{o}}$ value is $4 \mathrm{db}$, then for 6 sectors, the number of simultaneous users will be 88 but for 3 sectors, the number of simultaneous users will be 45 . Thus the dynamic values of $\mathrm{E}_{\mathrm{b}} / \mathrm{N}_{\mathrm{o}}$ can be the increasing or decreasing factors in UMTS and sectorization scheme can be effective in this case.

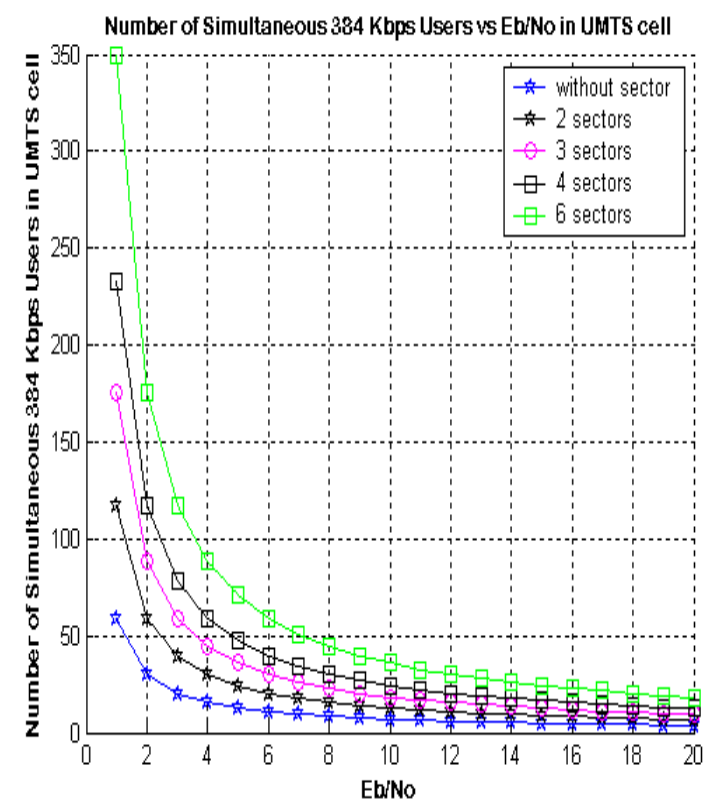

Figure 3: Number of simultaneous $384 \mathrm{Kbps}$ users vs. Eb/No in sectors cell

TABLE 3: SIMULATED VALUES FOR NUMBER OF SIMULTANEOUS 384 KBPS USERS VS. EB/NO IN SECTORS CELL

\begin{tabular}{|c|c|c|c|c|c|}
\hline $\begin{array}{c}\text { Energy per } \\
\text { bit to Noise } \\
\text { spectral } \\
\text { density } \\
\left.\text { ratio( } \mathbf{E}_{\mathbf{b}} / \mathbf{N}_{\mathbf{o}}\right)\end{array}$ & $\begin{array}{c}\text { Users } \\
\text { without } \\
\text { sector }\end{array}$ & $\begin{array}{c}\text { Users } \\
\text { with 2 } \\
\text { sectors }\end{array}$ & $\begin{array}{c}\text { Users } \\
\text { with 3 } \\
\text { sectors }\end{array}$ & $\begin{array}{c}\text { Users } \\
\text { with 4 } \\
\text { sectors }\end{array}$ & $\begin{array}{c}\text { Users } \\
\text { with 6 } \\
\text { sectors }\end{array}$ \\
\hline 1 & 59.065 & 117.13 & 175.19 & 233.26 & 349.39 \\
\hline 4 & 15.516 & 30.032 & 44.548 & 59.065 & 88.097 \\
\hline 8 & 8.2581 & 15.516 & 22.774 & 30.032 & 44.548 \\
\hline 10 & 6.8065 & 12.613 & 18.419 & 24.226 & 35.839 \\
\hline 14 & 5.1475 & 9.2949 & 13.442 & 17.59 & 25.885 \\
\hline
\end{tabular}

\begin{tabular}{|l|l|l|l|l|l|}
\hline 16 & 4.629 & 8.2581 & 11.887 & 15.516 & 22.774 \\
\hline 18 & 4.4156 & 7.4516 & 10.677 & 13.903 & 20.355 \\
\hline 20 & 3.9032 & 6.8065 & 9.7097 & 12.613 & 18.419 \\
\hline
\end{tabular}

The interference from other cell is known as inter-cell interference $(\beta)$. For multi-cell configuration, the number of outer cells can reduce cell capacity in UMTS. Figure 4 shows, for increasing demand of users the value of $\beta$ in UMTS needs to be small. Figure 4 also represents dynamic inter-cell interference with changing of sectors, where number of simultaneous $384 \mathrm{Kbps}$ data users increases or decreases. From Figure 4 it has been observed that for increasing value of $\beta$, it is needed to increase sectors.

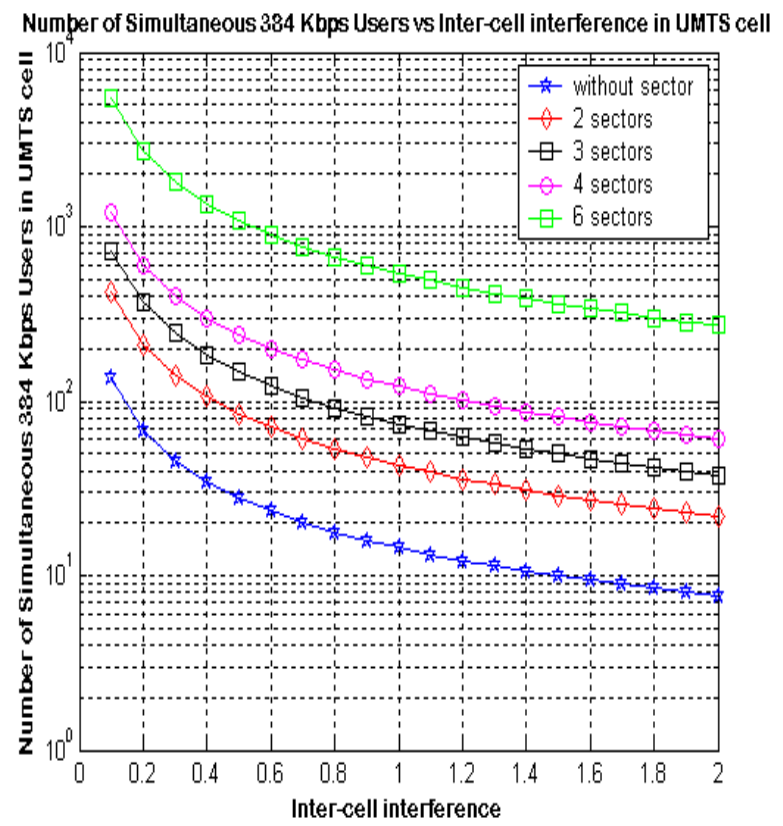

Figure 4: Number of simultaneous $384 \mathrm{Kbps}$ users vs.inter-cell interference in sectors cell

The overlapped cell can lead an extra power thus introducing soft handover factor $(\mathrm{H})$ in a UMTS cell. The value of $\mathrm{H}$ in UMTS can be a factor to increase the number of users. Figure 5 shows that for increasing $\mathrm{H}$ and changing value of sectorization the number of simultaneous $384 \mathrm{Kbps}$ data users increases.

For example, if $\mathrm{H}$ value is $2.5 \mathrm{db}$, then for 2 sectors the number of simultaneous users will be 195 but for 4 sectors the number of simultaneous users will be 388 .

Figure 6 shows that the number of voice users depends on the value voice activity factors $(\alpha)$. This is true only for 12.2 Kbps voice users, not for data users, as for data services it will always be 1 .

Figure 3 also shows that, for increasing amount voice users the value of $\alpha$ in UMTS needs to as small as possible. Varying $\alpha$ and changing the sectors the number of simultaneous voice users from figure 6 is observed. 
TABLE 4: SIMULATED VALUES FOR NUMBER OF SIMULTANEOUS USERS VS. INTER-CELL INTERFERENCE IN SECTORS CELL

\begin{tabular}{|c|c|c|c|c|c|}
\hline $\begin{array}{c}\text { Inter- } \\
\text { cell } \\
\text { interfer } \\
\text { ence }\end{array}$ & $\begin{array}{c}\text { Users } \\
\text { without } \\
\text { sector }\end{array}$ & $\begin{array}{c}\text { Users } \\
\text { with } \\
\mathbf{2} \\
\text { sectors }\end{array}$ & $\begin{array}{c}\text { Users } \\
\text { with } \\
\mathbf{3} \\
\text { sectors }\end{array}$ & $\begin{array}{c}\text { Users } \\
\text { with } \\
\mathbf{4} \\
\text { sectors }\end{array}$ & $\begin{array}{c}\text { Users } \\
\text { with } \\
\text { 6 sectors }\end{array}$ \\
\hline 0.1 & 135.33 & 419.6 & 730.73 & 1201 & 5401 \\
\hline 0.5 & 27.866 & 84.721 & 146.95 & 241 & 1081 \\
\hline 1 & 14.433 & 42.86 & 73.973 & 121 & 541 \\
\hline 1.5 & 9.9552 & 28.907 & 49.649 & 81 & 361 \\
\hline 1.7 & 8.9017 & 25.624 & 43.925 & 71.588 & 53.941 \\
\hline 2.0 & 7.7164 & 21.93 & 37.486 & 61 & 271 \\
\hline
\end{tabular}

TABLE 5: SIMULATED VALUES FOR NUMBER OF SIMULTANEOUS USERS VS. SOFT HANDOVER FACTOR IN SECTORS CELL

\begin{tabular}{|c|c|c|c|c|c|}
\hline $\begin{array}{c}\text { Soft } \\
\text { Hand } \\
\text {-over } \\
\text { Factor }\end{array}$ & $\begin{array}{c}\text { Users } \\
\text { without } \\
\text { sector }\end{array}$ & $\begin{array}{c}\text { Users } \\
\text { with } \\
\text { 2 sectors }\end{array}$ & $\begin{array}{c}\text { Users } \\
\text { with } \\
\text { 3 sectors }\end{array}$ & $\begin{array}{c}\text { Users } \\
\text { with } \\
\text { 4 sectors }\end{array}$ & $\begin{array}{c}\text { Users } \\
\text { with } \\
\text { 6 sectors }\end{array}$ \\
\hline 0.1 & 4.871 & 8.7419 & 12.613 & 16.484 & 24.226 \\
\hline 0.4 & 16.484 & 31.968 & 47.452 & 62.935 & 93.903 \\
\hline 1 & 39.71 & 78.419 & 117.13 & 155.84 & 233.26 \\
\hline 1.5 & 59.065 & 117.13 & 175.19 & 233.26 & 349.39 \\
\hline 2.5 & 97.774 & 194.55 & 291.32 & 388.1 & 581.65 \\
\hline 3 & 117.13 & 233.26 & 349.39 & 465.52 & 697.77 \\
\hline
\end{tabular}

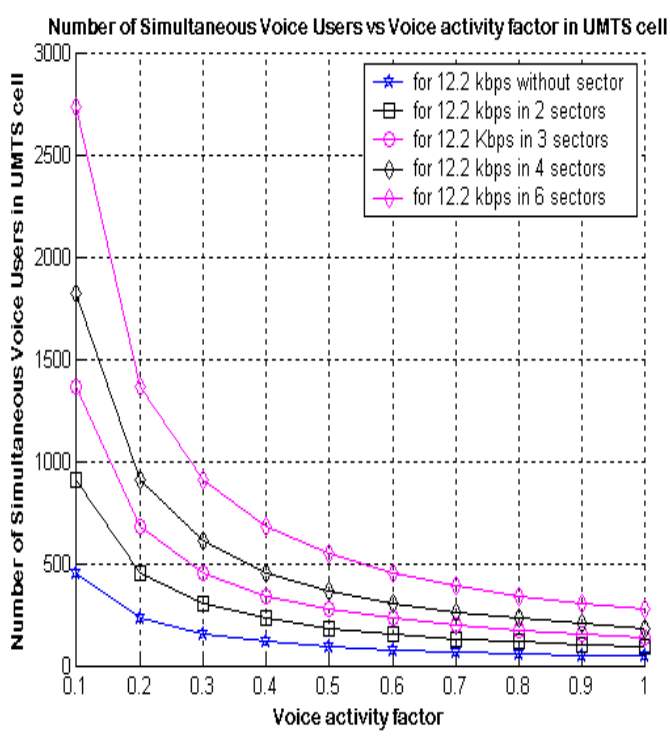

Figure 6: Number of simultaneous voice users vs. voice activity factor in sectors cell.

TABLE 6: SIMULATED VALUES FOR NUMBER OF SIMULTANEOUS USERS VS. VOICE ACTIVITY FACTOR IN SECTORS CELL

\begin{tabular}{|c|c|c|c|c|c|}
\hline $\begin{array}{c}\text { Voice } \\
\text { activity } \\
\text { factor }\end{array}$ & $\begin{array}{c}\text { Users } \\
\text { without } \\
\text { sector }\end{array}$ & $\begin{array}{c}\text { Users } \\
\text { with } \\
\text { 2 sectors }\end{array}$ & $\begin{array}{c}\text { Users } \\
\text { with } \\
\text { 3 sectors }\end{array}$ & $\begin{array}{c}\text { Users } \\
\text { with } \\
\text { 4 sectors }\end{array}$ & $\begin{array}{c}\text { Users } \\
\text { with } \\
\text { 6 sectors }\end{array}$ \\
\hline 0.2 & 228.31 & 455.63 & 682.94 & 910.26 & 1364.9 \\
\hline 0.4 & 114.66 & 228.31 & 341.97 & 455.63 & 682.94 \\
\hline 0.6 & 76.771 & 152.54 & 228.31 & 304.09 & 455.63 \\
\hline 0.8 & 57.828 & 114.66 & 171.49 & 228.31 & 341.97 \\
\hline 1 & 46.463 & 91.926 & 137.39 & 182.85 & 273.78 \\
\hline
\end{tabular}

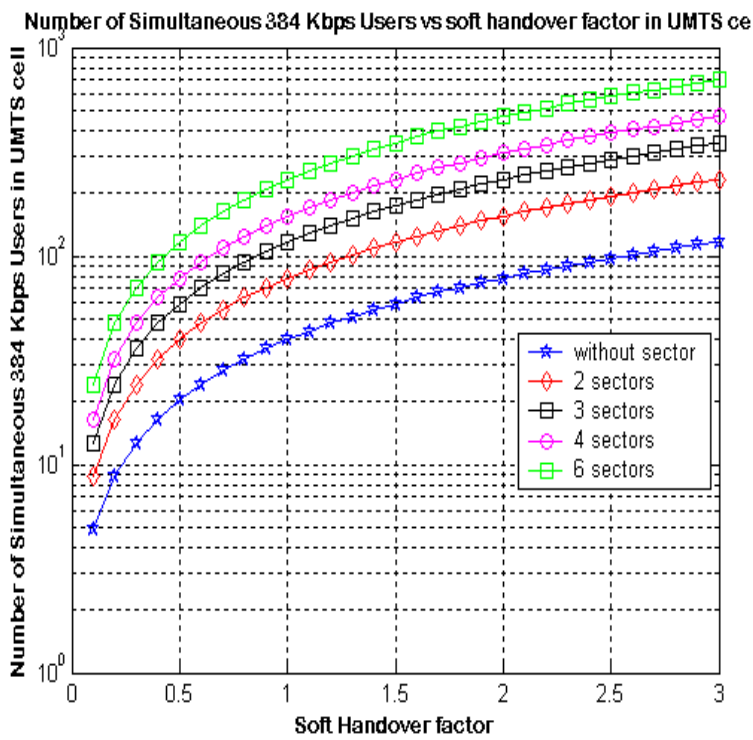

Figure 5: Number of simultaneous $384 \mathrm{Kbps}$ users vs. soft handover factor in sectors cell

www.ijacsa.thesai.org 
TABLE 7: SIMULATED VALUES FOR COVERAGE VS. DATA RATES IN DENSE URBAN USING COST 231 MODEL IN SECTORS CELL

\begin{tabular}{|c|c|c|c|c|c|}
\hline $\begin{array}{c}\text { Data } \\
\text { rate } \\
\text { (Kbps) }\end{array}$ & $\begin{array}{c}\text { Cell } \\
\text { range } \\
\text { in } \\
\text { (meter) }\end{array}$ & $\begin{array}{c}\text { Cell } \\
\text { Area } \\
\text { without } \\
\text { sector } \\
\left(\text { meter }^{2}\right)\end{array}$ & $\begin{array}{c}\text { Cell } \\
\text { Area } \\
\text { with 2 } \\
\text { sectors } \\
\text { (meter }^{2}\end{array}$ & $\begin{array}{c}\text { Cell } \\
\text { Area } \\
\text { with 3 } \\
\text { sectors } \\
\text { (meter }^{2}\end{array}$ & $\begin{array}{c}\text { Cell } \\
\text { Area } \\
\text { with 4 } \\
\text { sectors } \\
\text { (meter }^{2}\end{array}$ \\
\hline 200 & 773.67 & 598.57 & 778.14 & 1167.2 & 1556.3 \\
\hline 400 & 635.43 & 403.77 & 524.9 & 78.7 .34 & 1049.8 \\
\hline 600 & 566.31 & 320.71 & 416.92 & 625.38 & 833.84 \\
\hline 1000 & 489.83 & 239.94 & 311.92 & 467.88 & 623.84 \\
\hline 1200 & 465.12 & 216.33 & 281.23 & 421.85 & 562.47 \\
\hline 1400 & 445.19 & 198.2 & 257.66 & 386.49 & 515.31 \\
\hline 1600 & 428.63 & 183.72 & 238.84 & 358.26 & 477.67 \\
\hline 1800 & 414.53 & 171.83 & 223.38 & 335.07 & 446.76 \\
\hline 2000 & 402.31 & 161.85 & 210.41 & 315.61 & 420.81 \\
\hline
\end{tabular}

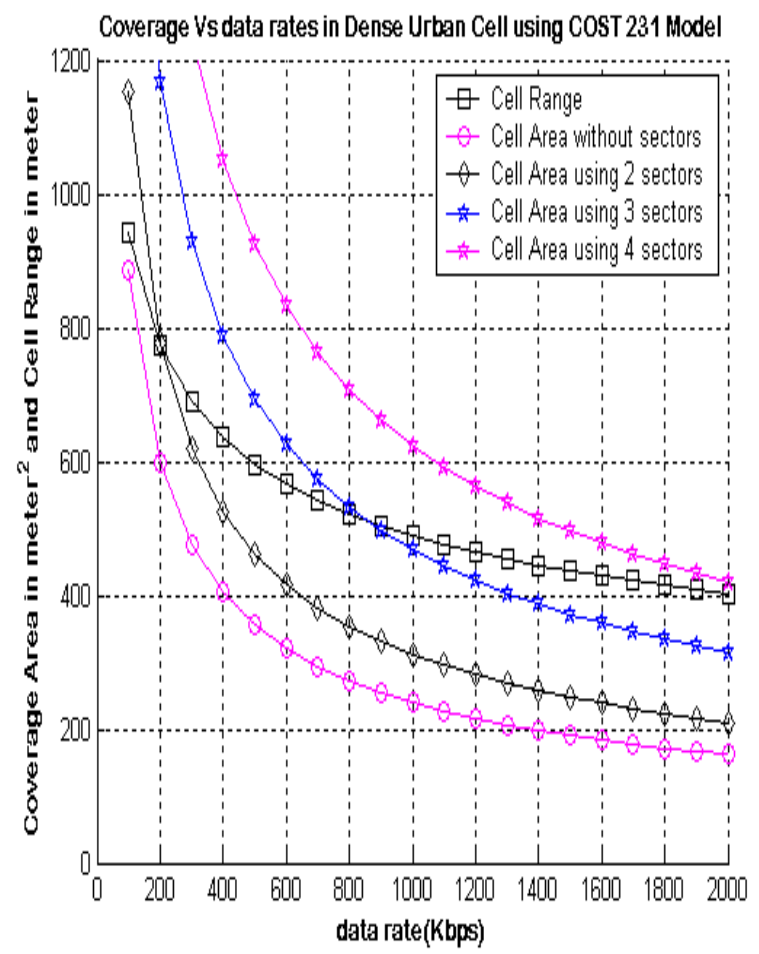

Figure 7: Coverage vs. bit rates for dense urban using COST 231 model in sectors cell
Finally, consider for coverage vs. data rates in dense urban area, where operating frequency is considered $2000 \mathrm{MHz}$ with COST 231 Model as a radio propagation model. In Figure 7 the $\mathrm{x}$ axis represents data rate in Kbps and $\mathrm{y}$ axis represents coverage area in meter ${ }^{2}$ with cell radius in meter. Parameters that are related to coverage setting first, then for increasing data rates in $\mathrm{x}$ axis, the coverage area is observed in y axis. From figure 1 , it is known that for higher data rates, the coverage will be smaller. It is true only when cell area is considered without sectors. This phenomenon is revealed by figure 7. Figure 7 also shows, for higher data rates comprehensive coverage area is found with increasing sectors.

\section{CONCLUSION}

In this paper, the performance analyses in coverage and capacity of UMTS cellular network using sectorization have been simulated and evaluated for dynamic parameters. The number of simultaneous users increases or decreases for increasing or decreasing sectors with dynamic parameters. Coverage has been estimated for dense urban using COST 231 model where higher data rates need higher processing gain resulting in smaller coverage area. But increasing sectors with same parameters makes extensive coverage for higher data rates.

\section{REFERENCES}

[1] Bo Hagerman, Davide Imbeni and Jozsef Barta "WCDMA 6 - sector Deployment-Case Study of a Real Installed UMTS-FDD Network" IEEE Vehicular Technology Conference, spring 2006, page(s): 703 707.

[2] S. Sharma, A.G. Spilling and A.R. Nix "Adaptive Coverage for UMTS Macro cellsbased on Situation Awareness". IEEE Vehicular Technology Conference, spring 2001, page(s):2786 - 2790

[3] A. Wacker, J. Laiho-Steffens, K. Sipila, K. Heiska, "The impact of the base station sectorisation on WCDMA radio network performance", IEEE Vehicular Technology Conference ,September 1999,page(s): 2611 -2615 vol.5.

[4] Romeo Giuliano, Franco Mazzenga, Francesco Vatalaro, "Adaptive cell sectorization for UMTS third generation CDMA systems" IEEE Vehicular Technology Conference, May 2001, page(s): 219 - 223 vol.1.

[5] T.S.Rappaport, "Wireless Communications Principles and Practice"-Second Edition, Prentice Hall.

[6] Bernard Sklar, "Digital Communications - Fundamentals and Applications"- Second Edition Prentice Hall.

[7] Ingo Fo, Marc Schinnenburg, Bianca Wouters "Performance EVALUATION OF SOFT HANDOVER IN A REALISTIC UMTS NETWORK" IEEE VEHICUlAR TECHNOLOGY CONFERENCE, SPRING 2003, PAGE(S): 1979 - 1983 VOL. 3.

[8] HaRri Holma and ANTTI TOSKALA, "WCDMA FOR UMTS-RADIO ACCESS THIRD GENERATION MOBILE COMMUNICATIONS"- JOHN WILEY \& SONS.

[9] Jaana Laiho, Achim Wacker, Tomas Novosad, "Radio Network Planning and Optimisation for UMTS"-Second Edition John Wiley \& Sons.

[10] A. Skopljak, "Multiantenna CDMA systems and their usage in $3 \mathrm{G}$ network", University of Sarajevo, 2007.

[11] Faruque, Saleh, "Cellular Mobile System Engineering", Artech House Publishers, 1996.

[12] Jhong Sam Lee, Leonard E. Miller, "CDMA Systems Engineering Handbook"-Artech House Publishers. 


\section{Appendix}

Begin

\section{Algorithm for Capacity Analysis Using Sectorization:}

Set energy per bit to noise spectral density ratio $(\mathrm{Eb} / \mathrm{No})=\left[\begin{array}{ll}1 & 23456789101620\end{array}\right]$

Set soft handover gain $(\mathrm{H})$ factor $=\left[\begin{array}{lllll}0.1 & 1 & 1.5 & 2 & 3\end{array}\right]$

Set inter-cell interference $(\beta)=\left[\begin{array}{llll}.1 & 1.2 & 1.55 & 2\end{array}\right]$

Set channel activity for data $(\alpha)=[1]$

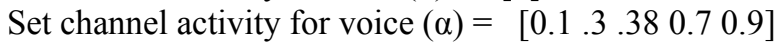

Set thermal noise $(\eta)$ in $(20$ Kelvin $) \mathrm{dbm} / \mathrm{Hz}=[-173.93]$

Set user signal power $(\mathrm{S} 1)$ in $\mathrm{dbm}=[21]$

Set shadow fading $\left(\mathrm{sh} \_\mathrm{fd}\right)$ in $\mathrm{db}=[8]$

Set cell range in $\mathrm{Km}\left(\mathrm{R}_{\text {cell }}\right)=[2]$

Set chip rate $(\mathrm{W})=[3840000]$

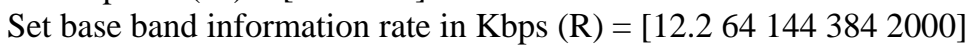

Set base antenna height in meter $\left(\mathrm{h}_{\mathrm{b}}\right)=[20]$

Set user antenna height in meter $\left(\mathrm{h}_{\mathrm{UE}}\right)=[2]$

Set sector $(D)=\left[\begin{array}{lllll}1 & 2 & 3 & 4 & 6\end{array}\right]$

Set frequency range in $\mathrm{MHz}\left(\mathrm{f}_{\mathrm{c}}\right)=$ [2000]

Set data rate in Kbps $(\mathrm{R})=\left[\begin{array}{l}12.2641443842000\end{array}\right]$

Set array antenna gain $\left(A_{g}\right)$ in $d b=\left[\begin{array}{llll}1 & 2 & 3.5 & 5\end{array}\right]$

//Processing

Processing gain $(\mathrm{PG})=10 \log (\mathrm{W} / \mathrm{R})$

Propagation loss in dense urban (Pro_loss) =

$46.3+33.9 \log \left(f_{c}\right)-13.82 \log h_{b}-3.2\left[\log \left(11.75_{\mathrm{UE}}\right)\right]^{2}+4.97+\left(44.9-6.55 \log h_{b}\right) \log d+3$

Signal Power $(\mathrm{S})$ = S1-Pro_loss-sh_hd

//Output

Number of Users $N_{s}=1+\left(\frac{W / R}{E_{b} / N_{o}}-\frac{\eta}{S}\right) \frac{1}{(1+\beta) \alpha} \times D \times H \times A_{g}$

End

Begin

Algorithm for Coverage and Data rates Analysis Using Sectorization:

Set Transmitter=User Equipment

Set Receiver=Node B

Set mobile max power in dbm (mo_mx) $=[21]$

Set mobile gain in db $($ M_G $)=[0]$

Set cable and connector losses in db (ca_cn_loss) $=[3]$

Set thermal noise in $\mathrm{dbm} / \mathrm{Hz}(\eta)=[-173.93]$

Set node B noise figure in $\mathrm{db}($ nodeB_NF) $=[5]$

Set target load (tar_ld) $=$ [.4]

Set chip rate $(\mathrm{W})=[3840000]$

Set base antenna height in meter $\left(h_{b}\right)=[20]$

Set user antenna height in meter $\left(\mathrm{h}_{\mathrm{UE}}\right)=[2]$

Set energy per bit to noise spectral density ratio $(\mathrm{Eb} / \mathrm{No})=[5]$

Set Power Control Margin or Fading Margin $(\mathrm{MPC})=[4]$

Set Value for sectors $(\mathrm{Sec})=\left[\begin{array}{llll}1 & 2 & 3 & 4\end{array}\right]$

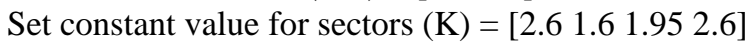

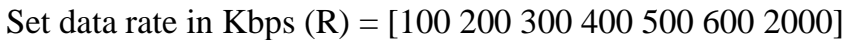

//Processing

Chip rate in $(\mathrm{W})=[3840000]$

Processing gain $(\mathrm{PG})=(\mathrm{W} / \mathrm{R})$

Effective isotropic radiated power $($ EIRP $)=$ mo_mx-ca_cn_loss + M_G

Node B noise density (nodeB_ND) $=\eta+$ nodeB_NF

Node B noise power $($ nodeB_NPW $)=$ nodeB_ND $+\mathrm{W} \_\mathrm{db}$

Interference margin $(\mathrm{IM})=-10 \log \left(1-\operatorname{tar} \_l d\right)$ 
Node B Interference Power $($ nodeB_IP $)=10 \log \left(10^{\text {(noisepowertInterfrenceM } \arg \text { in }) / 10}-10^{\text {Noisepower } 10}\right)$

Node B Noise and interference (nodeB_NIFPW $)=10 \log \left(10^{\text {(noisepowen } / 10}-10^{(\text {Interfrencepower)/10 }}\right)$

Node B antenna gain (NodeB_AG) in $\mathrm{db}=[18]$

Receiver Sensitivity $\left(\mathrm{S}_{\mathrm{rx}}\right)=\mathrm{Eb} / \mathrm{No}-\mathrm{PG}+$ nodeB_NIFPW

Total Allowable Path loss=EIRP-S ${ }_{\mathrm{rx}}+$ nodeB_AG-MPC=EIRP-(E $/ \mathrm{N}_{\mathrm{o}}-\mathrm{PG}+$ nodeB_NIFPW $)+$ NodeB_AG-MPC

Path loss in dense urban (Durban_Ploss) =

$$
\begin{aligned}
& 46.3+33.9 \log \left(f_{c}\right)-13.82 \log h_{b}-3.2\left[\log \left(11.75_{\mathrm{UE}}\right)\right]^{2}+4.97+\left(44.9-6.55 \log h_{b}\right) \log d+3 \\
& =142.17+36.37 \log \mathrm{d}
\end{aligned}
$$

//Output

Cell radius $(\mathrm{d})=10^{\wedge}((1 / 36.37) *($ EIRP-(Eb/No-PG+ nodeB_NIFPW $)+$ nodeB_AG-MPC-142.17) $)$

Cell Area $(A)=K^{*} d 2$

End 